\author{
JAN BYRSKI \\ https://doi.org/10.33995/wu2019.3.2
}

\title{
Przetwarzanie danych osobowych przez pośredników ubezpieczeniowych
}

Celem artykułu jest przedstawienie kluczowych zagadnień zwiqzanych z przetwarzaniem danych osobowych przez pośredników ubezpieczeniowych - kwestii wynikajacych z ogólnego rozporzqdzenia o ochronie danych (RODO) oraz z ustawy dostosowujqcej polskie regulacje do RODO (tzw. ustawy sektorowej]. Kwestie ochrony danych osobowych przez pośredników ubezpieczeniowych sq niezmiernie ważne dla rynku. Niemniej ustawa o dystrybucji ubezpieczeń nie została zmieniona przez ustawę sektorowq. Niniejszy artykuł stanowi asumpt do szerszej dyskusji naukowej dotyczqcej zasadności wprowadzenia zmian w tym zakresie.

Słowa kluczowe: ogólne rozporządzenie o ochronie danych (RODO), ochrona danych osobowych w branży ubezpieczeniowej, przetwarzanie danych osobowych przez pośredników ubezpieczeniowych, tajemnica agenta ubezpieczeniowego, tajemnica brokera ubezpieczeniowego, zautomatyzowane podejmowanie decyzji, w tym profilowanie.

\section{Wprowadzenie}

Ogólne rozporządzenie o ochronie danych ${ }^{1}$ jest stosowane od ponad roku, ale kompleksowe i ciągłe wdrożenie wymogów wynikających z tego rozporządzenia nadal stanowi duże wyzwanie dla pośredników ubezpieczeniowych. Ze względu na szeroki zakres zmian w przepisach, w tym konieczność uwzględniania nowych zasad (m.in. privacy by default i privacy by design)², a także

1. Rozporządzenie Parlamentu Europejskiego i Rady (UE) 2016/679 z dnia 27 kwietnia 2016 r. w sprawie ochrony osób fizycznych w zwiazku z przetwarzaniem danych osobowych i w sprawie swobodnego przepływu takich danych oraz uchylenia dyrektywy 95/46/WE (ogólne rozporządzenie o ochronie danych), dalej: RODO.

2. Privacy by default oznacza domyślną ochronę danych osobowych. Zgodnie z tą zasadą należy projektować procesy przetwarzania danych osobowych w taki sposób, aby domyślnie przetwarzać tylko te dane, które są niezbędne do osiagnięcia celu przetwarzania. Privacy by design oznacza ochronę danych osobowych w fazie projektowania. Zgodnie z nią administrator danych musi uwzględnić właściwe środki techniczne i organizacyjne, aby zapewnić realizację wymogów wynikających z RODO. Szerzej na temat zasady privacy 
obowiązki związane z przeprowadzaniem oceny skutków dla ochrony danych w przypadku niektórych operacji przetwarzania (tzw. DPIA ${ }^{3}$ ), proces ten trudno uznać za zakończony.

W Komunikacie Prezesa Urzędu Ochrony Danych Osobowych w sprawie wykazu rodzajów operacji przetwarzania danych osobowych wymagających oceny skutków przetwarzania dla ich ochrony ${ }^{4}$ o sektorze ubezpieczeniowym wspomina się bezpośrednio w kilku miejscach. I tak:

- w pkt 1 - „Ewaluacja lub ocena, w tym profilowanie i przewidywanie (analiza behawioralna) w celach wywołujących negatywne skutki prawne, fizyczne, finansowe lub inne niedogodności dla osób fizycznych” - Komunikat wskazuje „Firmy ubezpieczeniowe” (jak się wydaje, w tym i pośredników ubezpieczeniowych występujących w roli administratora danych), które oferują zniżki związane ze stylem życia (papierosy, alkohol, sporty ekstremalne, styl jazdy samochodem ], podaje także przykład firmy ubezpieczeniowej przedstawiającej np. korzystniejsze oferty ubezpieczeniowe lub kredytowe dla pracowników określonych grup, np. administracji publicznej, nauczycieli;

- w pkt 5 - „Przetwarzanie danych biometrycznych wyłącznie w celu identyfikacji osoby fizycznej bądź w celu kontroli dostępu" - Komunikat wskazuje na systemy ewidencyjne operacji ubezpieczeniowych;

- w pkt ?. - „Dane przetwarzane na dużą skalę, gdzie pojęcie dużej skali dotyczy: liczby osób, których dane sa przetwarzane, zakresu przetwarzania, okresu przechowywania danych oraz geograficznego zakresu przetwarzania" jako przykład takiego systemu podaje centralny system obsługi ubezpieczeń komunikacyjnych.

Po uchwaleniu RODO, już od listopada 2016 roku trwały w kraju prace nad ustawą sektorowa ${ }^{5}$, która miała wprowadzić zmiany w licznych ustawach szczególnych. Prace te znacząco się przedłużyły, jednak długo wyczekiwane przepisy zostały uchwalone i weszły w życie w dniu 4 maja 2019 roku. Istotne zmiany, które zostały wprowadzone ustawą sektorową, dotyczą także przepisów ustawy z dnia 11 września 2015 roku o działalności ubezpieczeniowej i reasekuracyjnej ${ }^{6}$, dlatego podmioty branży ubezpieczeniowej, w tym pośrednicy ubezpieczeniowi, zmuszone zostały do dokonania ponownego przeglądu swoich procesów i dokumentacji pod kątem realizacji dodatkowych wymogów określonych w tych nowych przepisach. Ustawa sektorowa nie dokonała żadnych zmian w ustawie o dystrybucji ubezpieczeń?

by default i privacy by design zob. RODO. Ogólne rozporzqdzenie o ochronie danych. Komentarz do art. 25, [red.] E. Bielak-Jomaa, D. Lubasz, Wolters Kluwer, Warszawa 2018.

3. Art. $35 \mathrm{RODO} \mathrm{z}$ ang. Data protection impact assessment.

4. Komunikat Prezesa Urzędu Ochrony Danych Osobowych z dnia 17 czerwca 2019 r. w sprawie wykazu rodzajów operacji przetwarzania danych osobowych wymagajacych oceny skutków przetwarzania dla ich ochrony (M.P. 2019, poz. 666).

5. Ustawa z dnia 21 lutego 2019 r. o zmianie niektórych ustaw w związku z zapewnieniem stosowania rozporzadzenia Parlamentu Europejskiego i Rady (UE) 2016/679 z dnia 27 kwietnia 2016 r. w sprawie ochrony osób fizycznych w związku z przetwarzaniem danych osobowych i w sprawie swobodnego przepływu takich danych oraz uchylenia dyrektywy 95/46/WE (Dz. U. 2019, poz. 730).

6. Tekst jedn. Dz. U. 2018, poz. 999 z późn. zm.; dalej: u.dz.u.r.

7. Ustawa z dnia 15 grudnia 2017 r. o dystrybucji ubezpieczeń (Dz. U. 2018, poz. 2210 z późn. zm.), dalej: u.d.u. 
Poniżej przedstawiono kluczowe zmiany wprowadzone w związku z uchwaleniem ustawy sektorowej, a dotyczące branży ubezpieczeniowej - w szczególności pośredników ubezpieczeniowych $^{8}$. Omówiono także wybrane, a warte uwagi, zagadnienia dotyczące wymogów wynikających z przepisów RODO. Na zakończenie wskazano również postulaty zmian de lege ferenda, zwłaszcza w kontekście przepisów ustawy o dystrybucji ubezpieczeń.

\section{Dane osobowe a tajemnica zawodowa w działalności pośredników ubezpieczeniowych}

Za dane osobowe, zgodnie z art. 4 pkt 1 RODO, rozumie się informacje o zidentyfikowanej lub możliwej do zidentyfikowania osobie fizycznej („osobie, której dane dotyczą). Możliwą do zidentyfikowania osobą fizyczna jest osoba, którą można bezpośrednio lub pośrednio zidentyfikować, w szczególności na podstawie identyfikatora takiego jak imię i nazwisko, numer identyfikacyjny, dane o lokalizacji, identyfikator internetowy lub jeden bądź kilka szczególnych czynników określających fizyczną, fizjologiczna, genetyczną, psychiczna, ekonomiczną, kulturową lub społeczną tożsamość osoby fizycznej. Wattpliwości może budzić wyraźne wpisanie imienia i nazwiska lub identyfikatora internetowego ${ }^{9}$ jako odrębnego identyfikatora, który bezpośrednio lub pośrednio umożliwia zidentyfikowanie osoby. Wydaje się jednak, że należy interpretować tę część definicji przez pryzmat możliwości zidentyfikowania osoby fizycznej za pomocą konkretnego identyfikatora. Niektóre z nich dają takie możliwości, a niektóre nie; samo imię i nazwisko, bez żadnych dodatkowych informacji, w wielu sytuacjach uniemożliwia zidentyfikowanie osoby fizycznej ${ }^{10}$.

W motywie 14 RODO stwierdza się, że ogólne rozporządzenie nie obejmuje przetwarzania danych osobowych dotyczących osób prawnych, w szczególności przedsiębiorstw będących osobami prawnymi, w tym danych o firmie i formie prawnej oraz danych kontaktowych osoby prawnej. 0 ile nie ma watpliwości, że wpisanie w firmie lub formie prawnej osoby prawnej (także tzw. ułomnej osoby prawnej] danych osobowych nie powoduje stosowania ogólnego rozporządzenia do takiej sytuacji, o tyle watpliwości budzi stwierdzenie, że rozporządzenie nie dotyczy przetwarzania danych kontaktowych osoby prawnej. Możliwe są bowiem trzy wykładnie. Pierwsza, że jako dane kontaktowe osoby prawnej rozumie się jedynie adres elektroniczny, ogólny numer telefonu lub adres strony internetowej osoby prawnej. Druga, że jako dane kontaktowe osoby prawnej rozumie się ww. adresy lub inne oznaczenia osoby prawnej, które moga przy okazji zawierać również dane osobowe oraz dane dotyczące osób fizycznych ujawnione w publicznym, jawnym rejestrze, m.in. w rejestrze

8. Jako pośrednik ubezpieczeniowy rozumiany będzie agent ubezpieczeniowy, agent oferujący ubezpieczenia uzupełniające, broker ubezpieczeniowy oraz broker reasekuracyjny, którzy wykonują dystrybucję ubezpieczeń albo dystrybucję reasekuracji za wynagrodzeniem (art. 3 ust. 1 pkt 15 u.d.u.).

9. Zob. jednak wyrok wydany jeszcze na podstawie dyrektywy 95/46/WE Trybunału Sprawiedliwości Unii Europejskiej druga izba) z dnia 19 października 2016 r. w sprawie C-582/14 (http://curia.europa.eu/juris/document/document.jsf;jsessionid=8FBOBBA4C78110BCB6FD90B81139EOEO?text=\&docid=184668\&pagelnd ex=0\&doclang=PL\&mode=Ist\&dir=\&occ=first\&part=1\&cid=5196248 [dostęp: 29.09.2019]]

10. Na temat anonimizacji i pseudonimizacji danych osobowych zob. J. Byrski, Outsourcing w działalności dostawców usług płatniczych, CH Beck, Warszawa 2018, s. 36?-370. 
przedsiębiorców Krajowego Rejestru Sądowego ${ }^{11}$. Trzecia, że dotyczy to także danych kontaktowych osoby prawnej rozumianych jako dane osobowe osoby fizycznej wyznaczonej do kontaktów w imieniu osoby prawnej, niekoniecznie jedynie wynikające z jawnego, publicznego rejestru ${ }^{12}$.

Ogólne rozporządzenie przewiduje w art. 9 ust. 1 RODO ogólny zakaz przetwarzania szczególnych kategorii danych osobowych ${ }^{13}$. Do danych szczególnie chronionych zostały wprowadzone dwie nowe kategorie danych, o których wcześniej nie było mowy w dyrektywie 95/46/WE ${ }^{14}$ oraz w starej ustawie o ochronie danych osobowych ${ }^{15}$, tj. dane genetyczne ${ }^{16}$ oraz biometryczne ${ }^{17}$. Dane genetyczne to dane osobowe dotyczące odziedziczonych lub nabytych cech genetycznych osoby fizycznej, które ujawniają niepowtarzalne informacje o fizjologii lub zdrowiu tej osoby i które wynikają w szczególności z analizy próbki biologicznej pochodzącej od tej osoby fizycznej ${ }^{18}$. Natomiast dane biometryczne oznaczają dane osobowe, które wynikają ze specjalnego przetwarzania technicznego, dotyczą cech fizycznych, fizjologicznych lub behawioralnych osoby fizycznej oraz umożliwiają lub potwierdzaja jednoznaczną identyfikację tej osoby - są to m.in. wizerunek twarzy czy dane daktyloskopijne ${ }^{19}$.

W działalności pośredników ubezpieczeniowych może dochodzić do przetwarzania danych biometrycznych w celu jednoznacznego zidentyfikowania osoby fizycznej, np. przy pozyskiwaniu danych daktyloskopijnych lub kształtu twarzy w celu identyfikacji ubezpieczonego przy wykorzystywaniu urządzeń elektronicznych ${ }^{20}$.

11. Rozporzqdzenie UE w sprawie ochrony osób fizycznych w zwiqzku z przetwarzaniem danych osobowych i swobodnym przepływem takich danych. Komentarz, [red.] P. Litwiński, CH Beck, Warszawa 2018, s. 17?, wskazując na osoby sprawujące funkcję organów osób prawnych. Wyrok TSUE z 20.5.2003 r., sprawy połączone C 465/00, C 138/01 oraz C 139/01 Osterreicherrundfunk i in., CURIA, pkt 73.

12. Zob. szerzej J. Byrski, op. cit., s. 363-364. Skłaniam się do przyjęcia drugiej wykładni, jednak Prezes UODO, jak się wydaje, przyjmuje pierwszą interpretację. Zob. decyzje Prezesa UODO dot. Fundacji ePaństwo.

13. Ogólne rozporządzenie nadto wyróżnia również dane dotyczące wyroków skazujących oraz naruszeń prawa (art. 10 RODO) jako odrębną kategorię danych osobowych, które jednak w bardzo ograniczonym zakresie mogłyby być przetwarzane przez dostawców usług płatniczych.

14. Dyrektywa Parlamentu Europejskiego i Rady 95/46/WE z dnia 24 października 1995 r. w sprawie ochrony osób fizycznych w zakresie przetwarzania danych osobowych i swobodnego przepływu tych danych (Dz. Urz. UE L 281 z 1995 r., s. 31 z późn. zm.).

15. Ustawa z dnia 29 sierpnia 1997 r. o ochronie danych osobowych (Dz. U. z 2002 r., Nr 101, poz. 202, z późn. zm. J, nieobowiązująca, dalej: s.u.o.d.o.

16. Szerzej na temat pojęcia danych genetycznych zob. Ł. Drożdżowski, Nowa definicja danych genetycznych, „Rzeczpospolita” 8 września 2017 r.

17. Do tej pory uważano, że dane biometryczne są danymi zwykłymi, chyba że sposób ich przetwarzania umożliwiałby ustalenie cech, które mają charakter danych wrażliwych. Por. szerzej D. Nowak, Szczególne kategorie danych osobowych - co nowego w rodo, „Ochrona Danych Osobowych” 2016, nr 10, s. 15.

18. Motyw 34 (preambuły) RODO wskazuje, że chodzi o informacje uzyskane z próbki biologicznej w szczególności na podstawie chromosomów, kwasu rybonukleinowego (RNA) lub z analizy innych elementów, które umożliwiają pozyskanie równoważnych informacji.

19. Motyw 51 (preambuły) RODO wskazuje na przykładzie fotografii, kiedy posiadane dane należy uznać za dane biometryczne. Definicja biometryczności obejmuje je tylko w przypadkach, gdy są przetwarzane specjalnymi metodami technicznymi, które umożliwiająjednoznaczną identyfikację osoby fizycznej lub potwierdzenie jej tożsamości.

20. Wydaje się, że definicji danych biometrycznych jako danych szczególnie chronionych, a więc danych biometrycznych w celu jednoznacznego zidentyfikowania osoby fizycznej, nie spełnia zwykłe zbieranie (na- 
Od sformułowania dane osobowe należy odróżnić pojęcie informacji stanowiącej tajemnicę zawodową. Dane osobowe pozostają w stosunku krzyżowania z informacjami stanowiącymi tajemnice zawodowe ${ }^{21}$. Artykuł 22 ust. 3 pkt 5 u.d.u. zobowiązuje agenta ubezpieczeniowego ${ }^{22}$ do zachowania w tajemnicy informacji uzyskanych w związku z wykonywaniem czynności agencyjnych, dotyczących zakładu ubezpieczeń, drugiej strony umowy ubezpieczenia lub umowy gwarancji ubezpieczeniowej oraz klienta ${ }^{23}$. Art. 32 ust. 3 pkt 1 u.d.u. zobowiązuje brokera ubezpieczeniowego do zachowania w tajemnicy informacji uzyskanych w związku z wykonywaniem czynności brokerskich w zakresie ubezpieczeń24 .

Należy potwierdzić, że ustawa o dystrybucji ubezpieczeń ustanowiła tajemnice zawodowe ${ }^{25}$ (tzw. tajemnica agenta ubezpieczeniowego oraz tajemnica brokera ubezpieczeniowego) odrębne od samej tajemnicy ubezpieczeniowej (art. 35 ust. 1 u.dz.u.r.) ${ }^{26}$. 0 ile agent ubezpieczeniowy i tak jest „pierwotnie” zobowiązany do zachowania tajemnicy ubezpieczeniowej na podstawie art. 35 ust. 1 u.dz.u.r. (zatem, co do zasady, występuje tożsamość zakresowa pojęć tajemnica agenta ubezpieczeniowego i tajemnica ubezpieczeniowa), o tyle nie można uznać brokera ubezpieczeniowego za podmiot, za pomocą którego zakład ubezpieczeń wykonuje czynności ubezpieczeniowe. Broker ubezpieczeniowy działa w imieniu osoby poszukującej ochrony ubezpieczeniowej i nie może wykonywać działalności agencyjnej ani czynności agencyjnych (art. 30 ust. 1 pkt 1 u.d.u.), a więc nie może działać w imieniu zakładu ubezpieczeń. W konsekwencji - broker ubezpieczeniowy jest zobowiązany jedynie do zachowania tajemnicy brokera ubezpieczeniowego.

grywanie) danych dotyczących głosu ubezpieczonego. Nagrywanie rozmów telefonicznych (głosu osoby fizycznej) nie służy zasadniczo umożliwieniu lub potwierdzeniu jednoznacznego zidentyfikowania osoby fizycznej, lecz jedynie utrwaleniu rozmowy telefonicznej. Aczkolwiek jeżeli dane dotyczące głosu będą wynikały ze specjalnego przetwarzania technicznego i będą służyły ww. celowi, będą mogły stanowić dane szczególnie chronione.

21. J. Byrski, Wybrane tajemnice zawodowe a prawna ochrona danych osobowych, [w:] Ochrona danych osobowych. Aktualne problemy i nowe wyzwania, [red.] G. Sibiga, X. Konarski, Wolters Kluwer 200?, s. 189.

22. Także agenta oferującego ubezpieczenia uzupełniające.

23. Słusznie ustawodawca w ustawie o dystrybucji ubezpieczeń rozszerzyłzakres tajemnicy agenta ubezpieczeniowego również o informacje dotyczące umowy gwarancji ubezpieczeniowej (art. 13 ustawy o pośrednictwie ubezpieczeniowym o tym nie stanowił) oraz zamienił pojęcie podmiotu szukającego ochrony ubezpieczeniowej na pojęcie klienta, co bardziej odpowiada wykonywanej roli agenta ubezpieczeniowego.

24. Ustawodawca w ustawie o dystrybucji ubezpieczeń doprecyzował, że w zakresie tajemnicy brokera ubezpieczeniowego znajdują się jedynie informacje uzyskane w związku z wykonywaniem czynności brokerskich w zakresie ubezpieczeń, a więc nie znajdują się informacje uzyskane w związku z wykonywaniem czynności brokerskich w zakresie innym niż ubezpieczeń. Trudno jednoznacznie ocenić tę zmianę, wprowadzoną w stosunku do ustawy o pośrednictwie ubezpieczeniowym, która tego doprecyzowania nie zawierała, a więc tajemnicą brokera ubezpieczeniowego objęte były wszystkie informacje pozyskane w związku z wykonywaniem czynności brokerskich. Z jednej strony, jak się wydaje, zmiana miała na celu zbliżenie pojęciowe tajemnicy brokerskiej do tajemnicy ubezpieczeniowej. Z drugiej strony, nie wiadomo dlaczego inne informacje pozyskane przez brokera ubezpieczeniowego - nie tylko te związane z wykonywaniem czynności brokerskich w zakresie ubezpieczeń - nie miałyby być przez niego chronione na podstawie tajemnicy brokerskiej?

25. Ma to znaczenie, gdyż RODO odnosi się m.in. w art. 14 ust. 5 lit. d do pojęcia tajemnicy zawodowej.

26. Tak, na podstawie nieobowiązującej już ustawy o pośrednictwie ubezpieczeniowym J. Byrski, Beneficjent tajemnicy ubezpieczeniowej, PA 2014, nr 2, s. 15-16. 


\section{Pośrednik ubezpieczeniowy i jego status na podstawie ogólnego rozporządzenia o ochronie danych}

Administratorem (danych), w myśl art. 4 pkt 7 ROD0, jest osoba fizyczna lub prawna (także ułomna osoba prawna), organ publiczny, jednostka lub inny podmiot, który samodzielnie lub wspólnie z inny$\mathrm{mi}^{27}$ ustala cele i sposoby przetwarzania danych osobowych. Jeżeli cele i sposoby takiego przetwarzania są określone w prawie Unii lub w prawie państwa członkowskiego, to również w prawie Unii lub w prawie państwa członkowskiego może zostać wyznaczony administrator lub mogą zostać określone konkretne kryteria jego wyznaczania. Podmiot przetwarzający oznacza osobę fizyczną lub prawną (również ułomną osobę prawna), organ publiczny, jednostkę lub inny podmiot, który przetwarza dane osobowe w imieniu administratora (art. 4 pkt 8 RODO). Nie zawsze określenie odpowiednich ról jest zadaniem prostym. W doktrynie zwraca się uwagę i krytykuje tzw. instrumentalizację instytucji powierzenia do przetwarzania danych osobowych ${ }^{28}$, a więc nie konkretnie zawarta umowa, a stan faktyczny przesądza o odpowiedniej roli na podstawie przepisów o ochronie danych osobowych.

Nie budzi wạtpliwości, że z uwagi na to, iż (wyłączny) agent ubezpieczeniowy nie jest administratorem danych osobowych osób, wobec których występuje jako przedstawiciel zakładu, działający w imieniu i na rzecz zakładu ubezpieczeń, nie musi on legitymować się samodzielną, odrębną od posiadanej przez zakład ubezpieczeń przesłanką legalności przetwarzania danych osobowych ${ }^{29}$. Agent, jako podmiot, któremu zakład ubezpieczeń w drodze zawartej umowy powierzył przetwarzanie danych, obowiązany jest przestrzegać, aby dane te przetwarzać wyłącznie w określonych w tej umowie celach i sposobach przetwarzania oraz zabezpieczyć je w sposób określony w przepisach o ochronie danych osobowych, zwłaszcza w art. 28 RODO30.

W nieco odmienny sposób przedstawia się sytuacja agentów niewyłącznych (tzw. multiagentów), tzn. agentów pracujących dla więcej niż jednej grupy ubezpieczeniowej. Mogą oni bowiem występować w podwójnej roli: podmiotu przetwarzającego i administratora (danych). Co do zasady, w zakresie zbiorów danych ${ }^{31}$ klientów zakładu ubezpieczeń, a więc osób, które zawarły już umowę ubezpieczenia, multiagent powinien być (podobnie jak agent wyłączny) traktowany jako podmiot przetwarzający ${ }^{32}$. Jednak w odniesieniu do danych osobowych potencjalnych klientów

27. Ogólne rozporządzenie o ochronie danych wprowadziło $w$ art. 26 RODO regulacje dotyczące współadministratorów. Zob. szerzej Rozporzqdzenie UE w sprawie..., s. 461-464.

28. G. Sibiga, Powierzenie przetwarzania danych osobowych w obrocie gospodarczym - wybrane zagadnienia, [w:] Prywatność a ekonomia. Ochrona danych osobowych w obrocie gospodarczym, [red.] A. Mednis, SAWPIA UW, Warszawa 2013, s. 105. Podobnie na gruncie RODO K. Witkowska-Nowakowska, [w:] RODO. Ogólne rozporzqdzenie ..., s. 635, wskazując, że prawidłowego przypisania pozycji prawnych znaczenie ma przede wszystkim funkcjonalna ocena rzeczywistych relacji, a nie sama umowa.

29. https://www.giodo.gov.pl/pl/362/995 [dostęp: 30.09.2019].

30. Zob. szerzej J. Byrski, Praktyczne aspekty umownego powierzenia danych, „ABI Expert” 2017, nr 4.

31. Mimo że art. 30 ust. 1 RODO odnosi się do rejestru czynności przetwarzania, a art. 30 ust. 2 RODO do rejestru wszystkich kategorii czynności przetwarzania, to jednak ogólne rozporządzenie nadal definiuje pojęcie „zbioru danych” w art. 4 pkt 6 RODO i posługuje się nim w motywach (preambuły) RODO i w art. 2 RODO.

32. Tak też na podstawie poprzedniego stanu prawnego projekt kodeksu dobrych praktyk PIU - https://piu.org. $\mathrm{pl} /$ public/upload/ibrowser/Dobre\%20praktyki\%200DO/KDP ODO Projekt w Koncowych Uzgodnienach z GIODO Publ WWW WRK? 22112012.pdf [dostęp: 30.09.2019]. 
multiagent może tworzyć własne zbiory danych i działać jako administrator. Wynika to z charakteru działalności multiagenta, który oferuje produkty różnych zakładów ubezpieczeń - nawet klientom, którzy pozostają stroną zawartej już umowy ubezpieczenia. Są wówczas traktowani przez multiagenta jako jego potencjalni klienci, którym może przedstawiać ofertę wielu zakładów ubezpieczeń. W takiej sytuacji należy uznać, że multiagenci decydują o celach i sposobach przetwarzania danych osobowych, niezależnie od zakładu ubezpieczeń, nie będąc jednak, jak się zdaje i co wynika z praktyki, współadministratorami danych ${ }^{33}$. W opisanym przypadku mamy zatem do czynienia z sytuacją, gdy multiagenci mogą przetwarzać te same dane osobowe, występując w różnych rolach. Warto jednak przypomnieć, że przetwarzając samodzielnie dane osobowe, multiagent powinien m.in. legitymować się stosowną przesłanką dopuszczalności przetwarzania danych osobowych (np. zgodą osób, których dane dotycza), wypełnić we własnym imieniu obowiązki informacyjne przewidziane w ogólnym rozporządzeniu o ochronie danych w stosunku do podmiotów danych oraz - co do zasady - prowadzić rejestr czynności przetwarzania.

Multiagentom należy też przypisać rolę administratorów ze względu na art. 2 pkt 3 lit. I ustawy o rozpatrywaniu reklamacji przez podmioty rynku finansowego i o Rzeczniku Finansowym ${ }^{34}$. Przepis ten definiuje pojęcie podmiotu rynku finansowego i wskazuje na agenta ubezpieczeniowego i agenta oferującego ubezpieczenia uzupełniające wykonujących czynności agencyjne na rzecz więcej niż jednego zakładu ubezpieczeń w zakresie tego samego działu ubezpieczeń, zgodnie z załącznikiem do ustawy o działalności ubezpieczeniowej i reasekuracyjnej w zakresie niezwiązanym z udzielaną ochroną ubezpieczeniową.

Dodatkowo agenci ubezpieczeniowi będą występować w roli administratora ze względu na brzmienie art. 2 ust. 1 pkt 9 ustawy o przeciwdziałaniu praniu pieniędzy oraz finansowaniu terroryzmu ${ }^{35}$. Artykuł ten do instytucji obowiązanej zalicza pośredników ubezpieczeniowych wykonujących czynności pośrednictwa ubezpieczeniowego w zakresie ubezpieczeń wymienionych w dziale I załącznika do u.dz.u.r., z wyłączeniem agenta ubezpieczeniowego, który jest agentem ubezpieczeniowym wykonujacym czynności pośrednictwa ubezpieczeniowego na rzecz jednego zakładu ubezpieczeń w zakresie tego samego działu zgodnie z ww. załącznikiem oraz nie pobiera od klienta składki ubezpieczeniowej ani od zakładu ubezpieczeń kwot należnych klientowi.

Podstawą legalności przetwarzania zwykłych danych osobowych przez brokerów ubezpieczeniowych są natomiast odpowiednio - zgoda osoby, której dane dotyczą (art. 6 ust. 1 lit. a RODO), jeśli chodzi o „potencjalnych” klientów, oraz niezbędność do wykonania umowy, której stronajest osoba, której dane dotyczą, lub do podjęcia działań na żądanie osoby, której dane dotyczą, przed zawarciem umowy (art. 6 ust. 1 lit. b RODO).

Przetwarzanie przez brokerów ubezpieczeniowych - podobnie jak w przypadku zakładów ubezpieczeń i multiagentów - danych osobowych klientów w celach marketingu bezpośredniego odbywa się na mocy art. 6 ust. 1 lit. f RODO ${ }^{36}$ lub na podstawie zgody podmiotu danych. Nie

33. W literaturze zwraca się też uwagę na możliwość współadministrowania danymi, zob. A. Wiercińska-Krużewska, M. Porzeżyński, [w:] Nowe zasady dystrybucji ubezpieczeń. Zagadnienia prawne, [red.] J. Pokrzywniak, Wolters Kluwer, Warszawa 2019, komentarz do art. 41.

34. Ustawa z z dnia 5 sierpnia 2015 r. o rozpatrywaniu reklamacji przez podmioty rynku finansowego i o Rzeczniku Finansowym (tekst jedn. Dz. U. 2018, poz. 2368).

35. Ustawa z dnia 1 marca 2018 r. o przeciwdziałaniu praniu pieniędzy oraz finansowaniu terroryzmu (tekst jedn. Dz. U. 2019, poz. 1115, z późn. zm.).

36. Por. motyw 47 (preambuły) RODO. 
jest wykluczone występowanie jednocześnie brokerów ubezpieczeniowych w roli podmiotów przetwarzających działających w imieniu innych podmiotów rynku ubezpieczeniowego (np. drugiego brokera ubezpieczeniowego].

\section{Zmiany w ustawie o działalności ubezpieczeniowej i reasekuracyjnej wpływające na działalność pośredników ubezpieczeniowych}

Z przewidzianych w u.dz.u.r. zmian związanych z dostosowaniem tej regulacji do ogólnego rozporządzenia o ochronie danych, a mogących mieć wpływ na pośredników ubezpieczeniowych, należy wymienić wprowadzenie:

A) ustawowej podstawy do przetwarzania określonych rodzajów i kategorii danych osobowych ${ }^{37}$;

B) profilowania, w tym na potrzeby podejmowania zautomatyzowanych decyzji;

C) braku wyjątku w realizacji obowiązku informacyjnego przez administratora danych ${ }^{38}$.

\section{A) Ustawowe podstawy prawne do przetwarzania określonych rodzajów i kategorii danych osobowych}

Ogólne rozporządzenie o ochronie danych określa zamknięty katalog przesłanek, na podstawie których dopuszczalne jest przetwarzanie danych osobowych. Katalog ten został określony odpowiednio w art. 6 ust. 1 RODO (tzw. dane zwykłe ${ }^{39}$ ) i w art. 9 ust. 2 RODO (dane szczególnej kategorii, tzw. dane wrażliwe ${ }^{40}$ ).

Nowe przepisy wprowadzone ustawą sektorową - mimo postulatów zgłaszanych w tym zakresie w trakcie prac legislacyjnych - nie wprowadzają samodzielnej podstawy prawnej dla przetwarzania zwykłych danych osobowych dla celów oceny ryzyka ubezpieczeniowego ${ }^{41}$. Co istotne, katalog danych osobowych, który został określony w art. 41 ust. 1 b u.dz.u.r., stanowi wyłącznie podstawę do podejmowania zautomatyzowanych decyzji przez zakład ubezpieczeń, zgodnie z art. 22 ust. 2 lit. b RODO, a nie podstawę prawną do przetwarzania danych zwykłych. Zakład ubezpieczeń powinien zatem oprzeć przetwarzanie danych osobowych w tym celu na innej podstawie wymienionej w RODO. W tym zakresie agent ubezpieczeniowy będzie działał w roli podmiotu przetwarzającego, a więc nie musi dysponować samodzielnie podstawa przetwarzania danych osobowych. Ocenę ryzyka ubezpieczeniowego zawsze podejmuje zakład ubezpieczeń.

37. W zakresie różnicy terminów rodzaj danych osobowych i kategorie danych osobowych zob. J. Byrski, Outsourcing $w$ działalności ..., s. 396.

38. Ważnym obowiązkiem dla pośredników ubezpieczeniowych jest również wyznaczenie inspektora ochrony danych. Przepisy ustawy sektorowej nie doprecyzowały jednak w tym zakresie art. 37 RODO.

39. Należy też te podstawy stosować do danych osobowych dotyczących wyroków skazujących i czynów zabronionych (art. 10 RODO).

40. Motyw 10 (preambuły) RODO posługuje się pojęciem danych wrażliwych, natomiast tytuł art. 9 RODO stanowi o szczególnych kategoriach danych.

41. Stanowisko Polskiej Izby Ubezpieczeń zawarte w piśmie do Ministra Cyfryzacji z dnia 5 września 2018 r.; znak PIU 1017/2018. 
Zdecydowanie więcej trudności dostarcza jednak ustalenie podstaw prawnych do przetwarzania danych wrażliwych, których zamknięty katalog został określony w art. 9 ust. 1 RODO ${ }^{42}$. Przetwarzanie takiego rodzaju danych osobowych jest zakazane, chyba że spełniony został jeden z warunków enumeratywnie wymienionych w art. 9 ust. 2 RODO. Nie sposób przy tym nie zauważyć, że w ramach prowadzenia działalności ubezpieczeniowej w wielu sytuacjach może dochodzić do przetwarzania takiego rodzaju danych, np. w związku z przetwarzaniem danych dotyczących zdrowia ubezpieczonych lub uprawnionych z umów ubezpieczenia. Z uwagi na specyfikę działalności ubezpieczeniowej takie przetwarzanie wydaje się więc niezbędne, oczywiście w zależności od rodzaju ubezpieczeń (w ramach ubezpieczeń osobowych, w tym ubezpieczeń następstw nieszczęśliwych wypadków, ubezpieczeń na życie etc.). Niezwykle istotne zatem było uwzględnienie podstawy do przetwarzania danych dotyczących zdrowia bezpośrednio w przepisach ustawy o działalności ubezpieczającej i reasekuracyjnej, żeby zagwarantować zakładom ubezpieczeń możliwość legalnego ich przetwarzania na podstawie art. 9 ust. 2 lit. g RODO ${ }^{43}$.

Pod koniec prac w Sejmie RP nad ustawą sektorowa wprowadzone zostały zmiany do brzmienia art. 41 ust. 1 u.dz.u.r. ${ }^{44}$ Treść przepisu budzi jednak watpliwości interpretacyjne, jako że mowa jest w nim wyłącznie o danych zawartych w: a) umowach ubezpieczenia; b) oświadczeniach składanych przed zawarciem umowy. Słusznie natomiast nowelizacja usunęła odniesienie jedynie do oświadczeń ubezpieczających - obecnie mogą to być czyjekolwiek oświadczenia. W literaturze przedmiotu zwrócono uwagę, aby przyjąć funkcjonalną wykładnię tego przepisu i uznać, że może chodzić również o dane zawarte w oświadczeniach składanych później, tj. w trakcie trwania (realizacji) umowy (np. w związku ze zdarzeniem ubezpieczeniowym), jeśli jest to niezbędne do wykonania umowy ubezpieczenia ${ }^{45}$.

Dla agentów ubezpieczeniowych działających w imieniu zakładu ubezpieczeń wystarczająca podstawa przetwarzania danych wrażliwych w wymienionych celach będzie zawarcie odpowiedniej umowy powierzenia do przetwarzania danych osobowych z zakładem ubezpieczeń. Dla brokerów ubezpieczeniowych brak obecnie analogicznej ustawowej podstawy prawnej do zbierania (przetwarzania) danych wrażliwych klientów.

Zasadne jest przyjęcie, że przetwarzanie danych dotyczących zdrowia wyjątkowo może też mieć miejsce w sytuacji wystapienia okoliczności określonych w art. 35a u.dz.u.r., tj. w celu i zakresie niezbędnym do zapobiegania przestępstwu, w przypadku uzasadnionego podejrzenia popełnienia przestępstwa na szkodę zakładu ubezpieczeń ( $\mathrm{np}$. w związku z podejrzeniem oszustwa

42. Przez „dane wrażliwe” należy rozumieć: dane osobowe ujawniające pochodzenie rasowe lub etniczne, poglądy polityczne, przekonania religijne lub światopoglądowe, przynależność do związków zawodowych, dane genetyczne, dane biometryczne przetwarzane w celu jednoznacznego zidentyfikowania osoby fizycznej, dane dotyczące zdrowia, seksualności lub orientacji seksualnej.

43. Zob. szerzej J. Byrski, H. Hoser, Zakres zmian w ustawie o działalności ubezpieczeniowej i reasekuracyjnej w zwiqzku z dostosowaniem do unijnych regulacji dotyczacych ochrony danych osobowych, „Prawo Asekuracyjne" 2019, nr 2, s. 75.

44. W treści przepisu przewidziano ostatecznie, że zakład ubezpieczeń przetwarza dane dotyczące zdrowia, ubezpieczonych lub uprawnionych z umowy ubezpieczenia, zawarte w umowach ubezpieczenia lub oświadczeniach składanych przed zawarciem umowy ubezpieczenia, odpowiednio w celu oceny ryzyka ubezpieczeniowego lub wykonania umowy ubezpieczenia, w zakresie niezbędnym z uwagi na cel i rodzaj ubezpieczenia.

45. J. Byrski, H. Hoser, op. cit., s. 76. 
ubezpieczeniowego ${ }^{46}$. W tym wypadku rola agenta ubezpieczeniowego również sprowadzałaby się do występowania jako podmiot przetwarzający działający w imieniu zakładu ubezpieczeń, o ile wykonywanie takich czynności zostanie mu powierzone. Broker ubezpieczeniowy nie dysponuje ustawowa podstawą do przetwarzania danych osobowych w celu zapobieganiu przestępstwom na szkodę brokera ubezpieczeniowego.

Dopuszczalność przetwarzania szczególnych kategorii danych osobowych może wynikać z innych przesłanek określonych w art. 9 ust. 2 RODO. W szczególności w razie wystapienia sporu cywilnego przetwarzanie danych dotyczących zdrowia przez zakład ubezpieczeń lub multiagenta, lub brokera ubezpieczeniowego może być niezbędne do ustalenia, dochodzenia lub obrony roszczeń lub w ramach sprawowania wymiaru sprawiedliwości przez sądy (art. 9 ust. 2 lit. f RODO), przy czym, zasadniczo podstawa ta może znaleźć zastosowanie dopiero na etapie postępowania sądowego ${ }^{4 ?}$.

\section{B) Profilowanie, w tym na potrzeby podejmowania zautomatyzowanych decyzji}

Profilowanie w sektorze ubezpieczeniowym ma istotne znaczenie, a jego rola stale wzrasta. Jak trafnie zauważyła Grupa robocza art. 29:48 „Za sprawą postępu technicznego i zdolności w zakresie analizowania dużych zbiorów danych, sztucznej inteligencji i uczenia się maszyn tworzenie profili i podejmowanie zautomatyzowanych decyzji jest coraz łatwiejsze i potencjalnie może w znacznym stopniu wpływać na prawa i wolności osób fizycznych"49.

Definicja legalna profilowania określona w ogólnym rozporządzeniu o ochronie danych (art. 4 pkt 4 RODO) została w analogicznym brzmieniu wprowadzona wart. 3 ust. 1 pkt 33a u.dz.u.r. Zgodnie z nią profilowanie musi mieć charakter automatyczny, przy czym, jak się wydaje, może być ono połączone z przetwarzaniem danych dokonywanym przez człowieka, na co zwrócono uwagę w literaturze ${ }^{50}$. Podobne stanowisko zajęła Grupa robocza art. 2951. Jakkolwiek można zauważyć, że w doktrynie pojawiają się także stanowiska, które sugerują, że profilowanie odnosi się wyłącznie do operacji realizowanych automatycznie ${ }^{52}$.

Profilowanie w zakładach ubezpieczeń daje szerokie możliwości, w szczególności w zakresie dotyczącym dokonywania oceny ryzyka ubezpieczeniowego, czy realizowania celów marketingowych, w tym dopasowywania ofert dla konkretnych osób z uwzględnieniem czynników

46. Zgodnie z art. 298 § 1 ustawy z dnia 6 czerwca 1997 r. - Kodeks karny (tekst jedn. Dz.U. 2018, poz. 1600 z późn. zm.): „Kto, w celu uzyskania odszkodowania z tytułu umowy ubezpieczenia, powoduje zdarzenie będące podstawą do wypłaty takiego odszkodowania, podlega karze pozbawienia wolności od 3 miesięcy do lat 5". W takim wypadku, zgodnie z art. 35b u.dz.u.r. wyłączony został art. 15 RODO w stosunku do zakładu ubezpieczeń.

47. Zob. motyw 52 (preambuły) RODO.

48. Grupa Robocza art. 29 ds. ochrony osób fizycznych w zakresie przetwarzania danych osobowych.

49. Wytyczne w sprawie zautomatyzowanego podejmowania decyzji windywidualnych przypadkach i profilowania do celów rozporzqdzenia 2016/679/UE,17/PL WP251rev.01, s. 5.

50. Zob. szerzej: RODO. Ogólne rozporzqdzenie...

51. Wytyczne w sprawie zautomatyzowanego podejmowania decyzji w indywidualnych przypadkach i profilowania do celów rozporzqdzenia 2016/679/UE, 17/PL WP251rev.01, s. ?.

52. Zob. P. Fajgielski, Komentarz do rozporzqdzenia 2016/679 w sprawie ochrony osób fizycznych w zwiqzku z przetwarzaniem danych osobowych i w sprawie swobodnego przepływu takich danych oraz uchylenia dyrektywy 95/46/WE logólne rozporzqdzenie o ochronie danych, [w:] Ogólne rozporzqdzenie o ochronie danych. Ustawa o ochronie danych osobowych. Komentarz, Wolters Kluwer, Warszawa 2018. 
osobowych dotyczących takiej osoby. Takie profilowanie może być wykonywane przy wykorzystaniu pośredników ubezpieczeniowych, zwłaszcza wyłącznych agentów ubezpieczeniowych lub multiagentów. Multiagenci i brokerzy ubezpieczeniowi w celu własnego marketingu bezpośredniego mogą również w swoim imieniu profilować dane osobowe klientów, dysponując w tym zakresie odpowiednia podstawa prawną.

Nie każda automatyczna operacja na danych osobowych, w której brane są pod uwagę czynniki osobowe musi skutkować profilowaniem. Istota profilowania jest bowiem dokonywanie pewnego rodzaju automatycznej oceny czynników osobowych (analiza lub prognoza dotycząca konkretnej osoby), kluczowy będzie zatem cel danej operacji ${ }^{53}$. Prosta klasyfikacja danych ze względu na znaną cechę (np. wiek) nie musi więc skutkować profilowaniem ${ }^{54}$.

Zasadniczo zarówno profilowanie, jak i zautomatyzowane podejmowanie decyzji poprzez profilowanie ${ }^{55}$ w branży ubezpieczeniowej może dotyczyć klientów lub potencjalnych klientów, lub byłych klientów. Nie da się jednak wykluczyć, że moga pojawić się inne sytuacje, w których takie działania będą miały miejsce, w tym niezwiązane z głównym przedmiotem prowadzonej działalności. Może to dotyczyć np. profilowania kandydatów do pracy (w tym np. automatycznego odrzucania kandydatur ${ }^{56}$.

Profilowanie, wbrew niekiedy pojawiającym się stanowiskom, nie powinno być przy tym uznawane za operację, która określa cel przetwarzania danych osobowych, a jedynie za rodzaj lub sposób przetwarzania danych osobowych. Przetwarzanie danych osobowych poprzez profilowanie zawsze jest wykonywane w określonym celu, np. dopasowania odpowiedniej oferty, wytypowania osób do akcji marketingowej czy oceny ryzyka ubezpieczeniowego ${ }^{5}$. Profilowanie nie jest więc celem per se. Nadmiarowe wydaje się w związku z tym - spotykane niekiedy w praktyce - poszukiwanie odrębnej podstawy prawnej na przetwarzanie danych osobowych i na profilowanie, skutkujące np. zbieraniem osobnej zgody na przetwarzanie danych osobowych w celu marketingu bezpośredniego oraz w celu profilowania marketingowego. Tym bardziej, że z art. 21 ust. 2 RODO explicite wynika, że marketing bezpośredni obejmuje profilowanie, a podstawa prawna jest prawnie uzasadniony interes administratora danych.

Profilowanie może mieć charakter profilowania zwykłego - tj. wspomagajacego procesy przetwarzania danych osobowych (np. w celu dopasowania marketingu produktów lub usług do spodziewanych potrzeb i preferencji osoby, której dane dotycza)], lub też mieć charakter profilowania kwalifikowanego, tj. służyć do zautomatyzowanego podejmowania decyzji w indywidualnych

53. Zob. szerzej: A. Mednis, Prawo ochrony danych osobowych wobec profilowania osób fizycznych, Presscom, Wrocław 2019, s. 173-174.

54. Zob. szerzej: Wytyczne w sprawie zautomatyzowanego podejmowania decyzji w indywidualnych przypadkach i profilowania do celów rozporzqdzenia 2016/679/UE, 17/PL WP251rev.01, s. ?.

55. Zob. szerzej na temat profilowania i zautomatyzowanego podejmowania decyzji: Polska i europejska reforma ochrony danych osobowych, [red.] E. Bielak-Jomaa, D. Lubasz, Wolters Kluwer, Warszawa 2016, s. 127-138; Byrski J., Oprogramowanie zawierajace elementy sztucznej inteligencji. Wybrane zagadnienia prawne, [w:] Experientia docet. Księga jubileuszowa ofiarowana Pani Profesor Elżbiecie Traple, [red.] P. Kostański, P. Podrecki, T. Targosz, Wolters Kluwer, Warszawa 2017, s. 1331-1342.

56. Zob. J. Byrski, H. Hoser, op. cit., s. 80.

57. Zob. szerzej: Ogólne rozporzqdzenie o ochronie danych osobowych. Wybrane zagadnienia, [red.] M. Kawecki, T. Osiej, CH Beck, Warszawa 201 ? 
przypadkach ${ }^{58}$. Grupa robocza art. 29 wyróżnia nawet trzy możliwe sposoby profilowania: „(i) profilowanie do celów ogólnych; (ii) podejmowanie decyzji na podstawie profilowania; oraz (iii) podejmowanie decyzji wyłącznie w sposób zautomatyzowany, w tym profilowanie, wywołujące wobec osoby, której dane dotyczą, skutki prawne lub w podobny sposób istotnie na nią wpływające (art. 22 ust. 1)"59.

W przypadku profilowania „zwykłego” wystarczające jest - co do zasady - posiadanie przez administratora podstawy prawnej dla przetwarzania danych osobowych w określonym celu oraz spełnienie w tym zakresie obowiązku informacyjnego. Przy profilowaniu kwalifikowanym, jeśli decyzja nie jest podejmowana faktycznie przez człowieka, to - mając na uwadze ogólny zakaz wynikajacy z art. 22 ust. 1 RODO - konieczne jest także wykazanie jednej z przesłanek określonych w art. 22 ust. 2 RODO. Przesłanka taka będzie konieczna zarówno w przypadku, gdy decyzja jest podejmowana wyłącznie w sposób zautomatyzowany (tj. na podstawie zaprogramowanych algorytmów bez żadnego udziału człowieka], jak i w wypadku, gdy decyzja jest zatwierdzana zasadniczo przez człowieka, jednak bez rzeczywistej analizy danych. Podejmowanie decyzji na podstawie profilowania nie zawsze musi zatem skutkować automatyczną decyzją w rozumieniu art. 22 ust. 1 RODO, pod warunkiem, że dane zostały faktycznie przeanalizowane przez człowieka.

W branży ubezpieczeniowej moga występować obydwa wskazane wyżej rodzaje profilowania ${ }^{60}$. Wydaje się, że dla pośredników ubezpieczeniowych występujących w roli administratorów główną rolę będzie odgrywało profilowanie zwykłe, które nie wiąże się z koniecznością analizy art. 22 RODO, a ze spełnieniem, jak już wskazano, m.in. obowiązku informacyjnego lub przeprowadzeniem oceny skutków dla ochrony danych (DPIA).

\section{C) Realizacja obowiązku informacyjnego przez administratora danych}

Zmiany wprowadzone do ustawy o działalności ubezpieczeniowej i reasekuracyjnej nie odnosza się bezpośrednio do kwestii realizacji obowiązku informacyjnego przez administratora danych (art. 13 lub 14 RODO) ${ }^{61}$, choć wyłączyły wobec zakładu ubezpieczeń stosowanie art. 15 RODO w odniesieniu do przetwarzania danych osobowych w zakresie realizacji zadań dotyczących przeciwdziałania praniu pieniędzy i finansowaniu terroryzmu.

Stosować zatem należy przepisy ogólnego rozporządzenia o ochronie danych. Warto zwrócić uwagę na obowiązki określone w art. 13 ust. 2 lit. f RODO i odpowiednio w art. 14 ust. 2 lit. g RODO. Z ogólnej zasady przejrzystości, a także z motywu 60 (preambuły) RODO wynika, że o fakcie profilowania należy każdorazowo poinformować osobę, której dane dotycza, ${ }^{62}$ - nie tylko wtedy gdy profilowanie jest związane z podejmowaniem automatycznej decyzji63. Administrator danych

58. J. Byrski, H. Hoser, op. cit.

59. Wytyczne w sprawie zautomatyzowanego podejmowania decyzji windywidualnych przypadkach i profilowania do celów rozporzqdzenia 2016/679/UE, 17/PL WP251rev.01, s. 9.

60. Szerzej omówione zasady profilowania kwalifikowanego przez zakłady ubezpieczeń zob. J. Byrski, H. Hoser, op. cit., s. 81-84.

61. Za wyjątkiem uchylenia art. 41 ust. 2 u.dz.u.r., który wyłączał art. 15 s.u.o.d.o.

62. Zob. szerzej Wytyczne w sprawie przejrzystości na podstawie rozporzqdzenia 2016/679, 17/PL WP260 rev.01, s. 24.

63. Odmiennie zob. Realizacja praw osób, których dane dotyczq, na podstawie rodo, PRESSCOM, [red.] B. Fischer, M. Sakowska-Baryła, Wrocław 2017, s. 109. 
powinien nadto poinformować o zautomatyzowanym podejmowaniu decyzji, w tym o profilowaniu, o którym mowa w art. 22 ust. 1 i 4 RODO, oraz o istotnych informacjach na temat zasad ich podejmowania, a także o znaczeniu i przewidywanych konsekwencjach takiego przetwarzania dla osoby fizycznej. Należy pamiętać, aby przekazywane informacje uwzględniały nowe przepisy ustawy o działalności ubezpieczeniowej i reasekuracyjnej. W przypadku, gdy to agent ubezpieczeniowy realizuje w imieniu zakładu ubezpieczeń obowiązek informacyjny, występuje on w roli podmiotu przetwarzającego.

Mając na uwadze konieczność zapewnienia przejrzystości przetwarzania, w tym obowiązek ułatwiania osobie realizacji przysługujących jej praw (art. 12 ust. 2 RODO) zasadne wydaje się nie tylko informowanie o „stosowaniu” automatycznych decyzji, zasadach ich podejmowania i konsekwencjach, ale także poinformowanie o prawie do uzyskania interwencji ludzkiej. Nie wydaje się jednak, aby taki obowiązek wynikał wprost z przepisów RODO lub ustawy sektorowej.

W sytuacjach, w których podstawa przetwarzania danych osobowych (w tym poprzez profilowanie) jest prawnie uzasadniony interes administratora danych, osoba, której dane dotyczą, powinna mieć zagwarantowaną możliwość zgłoszenia sprzeciwu i zostać o tym prawie poinformowana w klauzuli informacyjnej. Dotyczy to w szczególności przetwarzania do celów marketingowych. Niezbędne jest także wcześniejsze dokonanie ważenia prawnie uzasadnionego interesu administratora względem interesów lub podstawowych praw i wolności osoby fizycznej, co podkreślane jest zarówno w literaturze, jak i w orzecznictwie ${ }^{64}$.

Usunięcie art. 41 ust. 2 u.dz.u.r., który przewidywał wyłączenie wtórego obowiązku informacyjnego, ma daleko idące konsekwencje praktyczne dla administratorów danych z branży ubezpieczeniowej. Obecnie w zakresie niewypełnienia obowiązku informacyjnego z art. 14 RODO jedynej podstawy należy poszukiwać w art. 14 ust. 5 lit. a-d RODO 55.

Do przetwarzania danych osobowych przez zakład ubezpieczeń nie stosuje się art. 15 ROD0 (prawo dostępu przysługujące osobie, której dane dotycza) w zakresie, w jakim jest to niezbędne dla prawidłowej realizacji zadań dotyczących przeciwdziałania praniu pieniędzy i finansowaniu terroryzmu oraz zapobiegania przestępstwom ${ }^{66}$. Przepis ten nie znajdzie zastosowania do działalności ani multiagentów, ani brokerów ubezpieczeniowych. Należy de lege ferenda postulować wprowadzenie analogicznego zwolnienia względem multiagentów i brokerów ubezpieczeniowych do ustawy o dystrybucji ubezpieczeń.

64. Zob. przede wszystkim: RODO. Ogólne rozporzqdzenie ...; Wyrok NSA z dnia 27 marca 2018 r., I OSK 1459/16, LEX nr 2495188; Wyrok NSA z dnia 13 lutego 2014 r., I OSK 1641/12, LEX nr 1497276.

65. W zakresie analizy art. 14 ust. 5 RODO zob. szerzej J. Byrski, H. Hoser, Możliwości wyłaczenia wtórnego obowiqzku informacyjnego w świetle przepisów RODO, http://traple.pl/blog/mozliwosci-wylaczenia-wtornego-obowiazku-informacyjnego-w-swietle-przepisow-rodo/ [dostęp: 30.09.2019], a w odniesieniu do art. 14 ust. 5 lit. b RODO zob. J. Byrski, H. Hoser, Nałożenie administracyjnej kary pieniężnej za niezrealizowanie obowiqzku informacyjnego przy pozyskiwaniu danych z publicznie dostępnych źródeł - glosa do ostatecznej decyzji Prezesa Urzędu Ochrony Danych Osobowych z 15.03.2019 r. (ZSPR.421.3.2018), „Palestra” 2019, nr 5, s. $76-93$.

66. Art. $35 b$ u.dz.u.r. 


\section{Podsumowanie}

Przed pośrednikami ubezpieczeniowymi stoją duże wyzwania związane z koniecznością dostosowania swojej działalności nie tylko do wymogów ogólnego rozporządzenia o ochronie danych, ale także do przepisów ustawy sektorowej.

W pierwszej kolejności trzeba stwierdzić, czy następuje przetwarzanie danych osobowych w rozumieniu przepisów o ochronie danych osobowych, czy też innego rodzaju informacji (danych), a następnie, w jakiej relacji te informacje względem siebie występuja. W drugiej kolejności należy ustalić, w jakiej roli występuje pośrednik ubezpieczeniowy w odniesieniu do przetwarzania poszczególnych rodzajów i kategorii danych osobowych w określonych celach - administratora (danych), współadministratora czy podmiotu przetwarzającego, gdyż w konsekwencji tej analizy zostanie wyznaczony prawidłowy zakres obowiązków z przepisów o ochronie danych osobowych. Należy szczególnie pamiętać o przepisach ogólnego rozporządzenia o ochronie danych dotyczących obowiązku przeprowadzania oceny skutków dla ochrony danych (DPIA), przy uwzględnieniu wytycznych Grupy roboczej art. 29, jak również ostatniego Komunikatu Prezesa Urzędu Ochrony Danych Osobowych z dnia 17 czerwca 2019 roku.

Zasadne byłoby de lege ferenda rozważenie wprowadzenia w ustawie o działalności ubezpieczeniowej i reasekuracyjnej zmian w zakresie doprecyzowania art. 41 ust. 1 u.dz.u.r., poprzez jednoznaczne wskazanie, że zakład ubezpieczeń przetwarza dane dotyczące zdrowia ubezpieczonych lub uprawnionych z umowy ubezpieczenia, zawarte w oświadczeniach, w celu oceny ryzyka ubezpieczeniowego lub wykonania umowy ubezpieczenia, bez zastrzeżenia że chodzi o oświadczenia składane (jedynie) przed zawarciem umowy ubezpieczenia.

Ponadto niezbędne wydaje się przeanalizowanie zasadności wprowadzenia do ustawy o dystrybucji ubezpieczeń - analogicznych do wprowadzonych do ustawy o działalności ubezpieczeniowej i reasekuracyjnej - przepisów w zakresie:

1) podstawy prawnej dla brokerów ubezpieczeniowych do przetwarzania danych osobowych dotyczących zdrowia ubezpieczanych lub uprawnionych z umowy ubezpieczenia, w celu realizacji pełnomocnictwa do wykonywania czynności brokerskich w zakresie ubezpieczeń w imieniu klienta;

2) podstawy prawnej dla brokerów ubezpieczeniowych do przetwarzania danych osobowych, w tym danych dotyczących zdrowia lub danych osobowych objętych obowiązkiem zachowania tajemnicy, o którym mowa w art. 32 ust. 3 pkt 1 ustawy o dystrybucji ubezpieczeń, w przypadku uzasadnionego podejrzenia popełnienia przestępstwa na szkodę brokera ubezpieczeniowego w celu i zakresie niezbędnym do zapobiegania temu przestępstwu;

3) zwolnienia brokera ubezpieczeniowego i (niewyłacznego) agenta ubezpieczeniowego z realizacji prawa dostępu przysługującego osobie, której dane dotyczą (art. 15 RODO) w zakresie, w jakim jest to niezbędne dla prawidłowej realizacji zadań dotyczących przeciwdziałania praniu pieniędzy i finansowaniu terroryzmu oraz zapobiegania przestępstwom.

Z niezrozumiałych względów zarówno uzasadnienie do ustawy sektorowej, jak i inne dokumenty, które powstały podczas prac nad ustawą sektorową, milczą na temat konieczności lub zasadności wprowadzenia zmian w ustawie o dystrybucji ubezpieczeń ze względu na dostosowanie do ogólnego rozporządzenia o ochronie danych. 


\section{Wykaz źródeł}

Byrski J., Beneficjent tajemnicy ubezpieczeniowej, „Prawo Asekuracyjne” 2014, nr 2.

Byrski J., Oprogramowanie zawierajace elementy sztucznej inteligencji. Wybrane zagadnienia prawne, [w:] Experientia docet. Księga jubileuszowa ofiarowana Pani Profesor Elżbiecie Traple, Kostański P., Podrecki P., Targosz T. [red.], Wolters Kluwer, Warszawa 2017.

Byrski J., Outsourcing w działalności dostawców usług płatniczych, CH Beck, Warszawa 2018.

Byrski J., Praktyczne aspekty umownego powierzenia danych, „ABI Expert” 2017, nr 4.

Byrski J., Hoser H., Nałożenie administracyjnej kary pieniężnej za niezrealizowanie obowiqzku informacyjnego przy pozyskiwaniu danych z publicznie dostępnych źródeł - glosa do ostatecznej decyzji Prezesa Urzędu Ochrony Danych Osobowych z 15.03.2019 r. (ZSPR.421.3.2018), „Palestra” 2019, nr 5.

Byrski J., Hoser H., Zakres zmian w ustawie o działalności ubezpieczeniowej i reasekuracyjnej w zwiqzku z dostosowaniem do unijnych regulacji dotyczqcych ochrony danych osobowych, „Prawo Asekuracyjne” 2019, nr 2.

Fajgielski P., Komentarz do rozporzqdzenia nr 2016/679 w sprawie ochrony osób fizycznych w zwiqzku z przetwarzaniem danych osobowych i w sprawie swobodnego przepływu takich danych oraz uchylenia dyrektywy 95/46/WE (ogólne rozporzqdzenie o ochronie danych), [w: ] Ogólne rozporzadzenie o ochronie danych. Ustawa o ochronie danych osobowych. Komentarz, Wolters Kluwer, Warszawa 2018.

Mednis A., Prawo ochrony danych osobowych wobec profilowania osób fizycznych, Presscom, Wrocław 2019

Nowe zasady dystrybucji ubezpieczeń. Zagadnienia prawne, Pokrzywniak J. [red.], Wolters Kluwer, Warszawa 2019.

Ogólne rozporzq̨dzenie o ochronie danych osobowych. Komentarz, Sakowska-Baryła M. [red.], CH Beck, Warszawa 2018.

Ogólne rozporzqdzenie o ochronie danych osobowych. Wybrane zagadnienia, Kawecki M., Osiej T. [red.], CH Beck, Warszawa 2017.

Polska i europejska reforma ochrony danych osobowych, Bielak-Jomaa E., Lubasz D. [red.], Wolters Kluwer, Warszawa 2016.

Realizacja praw osób, których dane dotycza, na podstawie RODO, PRESSCOM, Fischer B., SakowskaBaryła M. [red.], Wrocław 2017.

RODO. Ogólne Rozporzqdzenie o ochronie danych. Komentarz, Bielak-Jomaa E., Lubasz D. [red.], Wolters Kluwer, Warszawa, 2018.

Rozporzqdzenie UE w sprawie ochrony osób fizycznych w zwiqzku z przetwarzaniem danych osobowych i swobodnym przepływem takich danych. Komentarz, Litwiński P. [red.], CH Beck, Warszawa 2018.

Sibiga G., Powierzenie przetwarzania danych osobowych w obrocie gospodarczym - wybrane zagadnienia, [w:] Prywatność a ekonomia. Ochrona danych osobowych w obrocie gospodarczym, Mednis A. [red.], SAWPIA UW, Warszawa 2013.

Ustawa o działalności ubezpieczeniowej i reasekuracyjnej. Komentarz, Czublun P. [red.], CH Beck, Warszawa 2016. 


\section{Processing of personal data by insurance intermediaries}

The purpose of the article is to present key issues related to the processing of personal data by insurance intermediaries - issues arising from the general data protection regulation (GDPR) and the act adapting Polish regulations to the GDPR (the so-called "sectoral act"). The issues of personal data protection by insurance intermediaries are extremely important for the market. However, the Insurance Distribution Act has not been amended by the sectoral act. This article is an incentive for a broader scientific discussion on the legitimacy of introducing changes in this area.

Key words: general data protection regulation (GDPR), personal data protection in insurance market, procesing of personal data by insurance intermediaries, insurance agent secrecy, insurance broker secrecy, automated individual decision-making, including profiling.

PROF. UEK DR HAB. JAN BYRSKI - profesor uczelni w Katedrze Prawa Gospodarczego Publicznego i Prawa Pracy w Instytucie Prawa Uniwersytetu Ekonomicznego w Krakowie, adwokat, wspólnik w Traple Konarski Podrecki i Wspólnicy.

e-mail: jan.byrski@traple.pl

nr orcid: 0000-0001-8335-3378 